\title{
Stereotypes and Sexualization of Girls and Adolescent Girls in Chilean Advertising: A Case Study
}

\section{Rayén Condeza-Dall'Orso}

Pontificia Universidad Católica de Chile (Chile) [Pontifical Catholic University of Chile (UC)] Pablo Matus

Pontificia Universidad Católica de Chile (Chile) [Pontifical Catholic University of Chile (UC)] Enrique Vergara-Leyton

Pontificia Universidad Católica de Chile (Chile) [Pontifical Catholic University of Chile (UC)]

This article presents a case study about three underwear and footwear advertising campaigns aimed at girls and adolescents in the context of the promotion of the back-to-school season in Chile in February 2020. The adverts caused social and media controversy. Social media users accused the brands of sexualizing children and adolescents' images for marketing and commercial ends. Based on an interpretative analysis of the graphic pieces involved in the campaigns, this article reflects on the representation of girls and adolescent girls. This research observes $a$ resort to female gender stereotypes char- acteristic of the fashion industry extended to childhood. Considering that advertising is one of the main discursive axes central in the social and media construction of infancy, we discuss the risk of normalizing communication strategies which appeal to the increasingly earlier seduction and erotization of infant and adolescent bodies through mass media despite prevailing ethical and self-regulation codes in the country.

Keywords: advertising, stereotypes, sexualization, girls-adolescents, fashion industry.

$\mathrm{T}$

he presence of girls and adolescent girls in fashion advertising campaigns constitute relevant problems approached by recent studies, in areas such as gender stereotypes, early erotization of their bodies by marketing, and the effects of socialization of individuals who grow up in a mediated and consumption society, with relevant communication spaces through social media (Bailey, 2011; Cervilla-Fernández and Marfil-Carmona, 2019; Díaz-Bustamante, Llovet-Rodríguez, 2017; Egan, 2013; González-Anleo, Cortés del Rosario, and Garcelán Vargas, 2013; Gunter et al., 2014; Liotard and Jamain-Samson, 2011; Merskin, 2004). 
The social and experts' concern about the erotization or sexualization of childhood with commercial ends by the fashion industry has been included in congress reports, such as in the United Kingdom (Bailey, 2011) and France (Jouanno, 2012). Not only do they criticize how inappropriate is to sexualize a girl to sell a product (Medina-Heredia and Méndiz-Noguero, 2012), but also the use of certain stereotypes of erotic and sexual connotation, which would operate as socialization figures of girls and adolescent girls (Liotard and Jamain-Samson, 2011), even more in a digital and social media environment (Gunter et al., 2014; Llovet-Rodríguez, Díaz-Bustamante and Méndiz-Noguero, 2019). Citing Potter (1965) and Jhally (1987), Caro (2014) holds that advertising has large power in the formation of people's norms and that it is the most influential socialization institution of modern societies.

In February 2020, a social controversy was triggered in Chile on social media, which expanded on to traditional media, regarding three advertising campaigns accused of resorting to the erotization of girls and adolescent girls' bodies, who appear modeling underwear, socks, and shoes, in the middle of back-to-school sale season. The controversy originated when a photographer, psychologist and women's rights activist called out on Twitter to withdraw an advert by a socks brand seen on display, which, according to her, sexualized the girl-model and might, to her judgement, foster pederasty (Lorenzini, 2020). Her tweet included a picture of the graphic piece, taken from one of the adverts at a shopping mall. She tagged Defensoría de la Niñez, ${ }^{1}$ an entity which also expressed their concerns.

In a few days, social media users as well as the press identified similar cases on an underwear brand's advert (a catalogue which circulated in digital print media) and in a footwear brand, with adolescents as protagonists (e.g., El Dínamo, 2020; Espinoza, 2020; T13, 2020). The arguments of the people who raised the concerns refer to sexist advertising, i.e., the use of images of women with sexual content as a persuasion tool, remarking "the social passivity and tolerance towards adverts which objectify the person and infringe upon their dignity" (Carretero-García, 2014: 130).

The criticism made by citizens (Urzúa, 2020), child sexual abuse prevention experts (Jackson, 2020) and government authorities (San Francisco and Badal, 2020), appealed to the responsibility of the brands on the inappropriate character of the images produced, their eroticizing or sexualized register of girls and adolescent girls in Chile. One of the brands publicly apologized and withdrew the adverts. Complaints were issued before the Self-Regulation and Advertising Council, ${ }^{2}$ which ruled in

1 Public and autonomous institution in charge of disseminating, protecting, and promoting the rights of children and adolescents in Chile ( $<w w w$.defensoriadelaninez.cl $>$ ).

2 Or CONAR (Consejo de Autorregulación y Ética Publicitaria), is a private corporation formed by the main guild entities of the industry - the Chilean Association of Advertising Agencies (Asociación Chilena de Agencias de Publicidad, ACHAP) and the National Association of Advertisers (Asociación Nacional de Avisadores, ANDA). Its objective is ethical self-regulation of the national advertising activity (<www.conar.cl $>$ ). 
favor of the plaintiffs. ${ }^{3}$ In addition, such entity asked to withdraw the campaigns from their different communication platforms (CONAR, 2020a, 2020b, and 2020c).

A similar media controversy occurred at a worldwide level in August 2020, when the streaming platform Netflix had to apologize for "the art used" to promote the french film Guapis (Mignones in its original French title, by Maimouna Docouré; a work of fiction which was awarded the best director prize at the Sundance Film Festival 2020), through a poster showing the group of the 11-year-old girls who star on the film in sensual attitude on the dancefloor, decontextualizing the original plot of the film (Garrido, 2020).

The analysis presented here is part of a broader investigation about the media construction of childhood. The article proposes to interpret the erotization of girls and adolescent girls in advertising as a stereotyping and early sexualization phenomenon, based on the pieces deemed inappropriate by the citizens and the infancy experts in Chile. This supposes recognizing the symbolic character of advertising within culture, the stereotyping of women and its expansion to the sexualization of childhood in advertising, defined as "the way in which girlsadolescents, within their social context, manifests certain aspects which are not their own, such as excessive femininity derived from sexual load" (DíazBustamante and Llovet-Rodríguez 2017: 78, quoting Arteaga-Villamil, 2010). In this case, the context of the commodification of the childhood image is added, specifically through the capitalization of its image as a sales strategy (AzevedoQueiroz and Alves dos Santos, 2018).

\section{THEORETICAL FRAMEWORK}

\section{Advertising: Symbolic and EThical Aspects}

Advertising is generically defined as a form of paid mediated communication, whose aim is to persuade the receiver to do a determined action (Richards and Curran, 2002: 74). Beyond that communicational-pragmatic dimension, it is also considered an agent of socialization and social cohesion (Berger, 2011; Caro, 2007), given its capacity of representation and resignification of the practices and values pertaining to a culture (Trindade and Silva, 2009; Vergara, 2006). For this reason, advertising is constituted as a symbolic referent of everyday life (Caro, 2014).

A way to explain this symbolic dimension is through the social imaginaries' theory, understood as groups of ideas and images (Escobar, 2000: 67) which act as thematic referents within the superior frame of culture (Baczko, 1991: 28). Imaginaries operate as a simplification of reality, allowing communities to understand and experiment phenomena or the material conditions of existence

3 See details of the processes appeals, and rulings at CONAR (<https://www.conar.cl/ casos/casos-completos/>). 
not explained by rational significations (Castoriadis, 1983: 254-255), as occurs, for instance, with the national identity (Anderson, 1993: 23-24). In this sense, imaginaries are regulatory forces of collective integration (Pintos, 1995: 108), and matrixes of social representations (Gómez, 2001: 198), i.e., of the stock of subjective interpretations of reality (Moscovici, 1984). Due to these characteristics, the mediated social discourse is fundamental for the constitution and dissemination of imaginaries (Baczko, 1991: 31), within which advertising fulfills a key role, circulating different types of social representations and stereotypes in different media (Hellín, 2007).

Recently, the "sexualisation of childhood" moved into the centre ground of public policy and debate internationally (Bragg and Buckingham, 2013) and it is important to think about the consequences for children and the consumer society (Llovet-Rodríguez, Díaz-Bustamante, and Patiño-Alves, 2016). One of the consequences of age compression is that kids are bombarded with adult content and messages that carry specific ideas not about childhood, but about what it means to be an adult (Speno and Aubrey, 2018: 628).

From an ethical perspective, "the moral dimension of the advertising action is linked to its ends, with the media it employs, the consequences that derive from its activity and, also, its source of social legitimacy" (Feenstra, 2014: 12). According to the Chilean Code of Advertisement ethics (CONAR, 2018: Article $22)$, "the participation of minors in advertising will avoid promoting situations and behaviors that are inappropriate for their age". Regarding advertising aimed to children, "special attention must be paid to the product promoted and the type of advertising is appropriate for infant and young audiences (Article 21). Likewise, such code specifically indicates about gender representation and stereotypes that "advertising messages must avoid statements and representations that denigrate people regarding their appearance, behavior, features or lifestyles, or that objectify them and reduce them to their sexuality" (Article 2).

\section{Women Stereotyping As Precedent of Erotization of Girls}

A stereotype is a representation which defines a group or category of beings based on the exacerbation of specific attributes, whether positive or negative (Schneider, 2004: 24). Hence it is always a reduction exercise and, as any social representation, a product of a psychological elaboration of the real (Jodelet, 1986: 474). The issue of stereotypes is relevant. They are a frequent topic in the research about social representations (Rosa, 2013) and the concern about their use in the media, especially when they refer to people's gender or sex, has a long history (Eisend, 2010; Herrett-Skjellum and Allen, 1996; Miller et al., 2018, Stankiewicz and Roselli, 2008). UN Women has attempted to sensibilize communicators on the meaningful role they play in perpetuating —or questioning — the social norms that tolerate discrimination or violence against women, girls, and adolescent girls, as well as the different stereotype forms associated to such violence (ONU Mujeres, 1995, 2020).

According to diverse contemporary research, the main media tendency is to reproduce gender inequality (Francisco-Heredero, 2019; Mensa and Bittner, 
2020) and representing women stereotypically as the object of sexual desire of men (Cáceres and Díaz, 2008; Lin, 1998; Maioli, 2017; Petroll and Damacena, 2012; Ribero, 2009; Serrano et al., 2018; Sherman, Allemand, and Prickett, 2020; Valiente-Bermejo, 2019; Zarza and Vélez, 2018). This should be interpreted as a reflection of beliefs and implicit assumptions regarding the interest of the public - men and women-, and not so much as a thorough representation of reality (Goffman, 1976). Negative stereotyping is a matter or representation based on imaginaries and significations present in society (Amâncio, 1993). In the sexualization of current culture appears a new feminine subject who "is incited to be compulsorily sexy and always "up for it'” (Gill, 2012: 486).

\section{Sexualization of Childhood in the Media}

Children and young people are not only exposed to increasing amount of hypersexualized images, but they are also sold the idea that they have to look "sexy" and "hot" (Egan, 2013). The evidence gathered since 2007 allows affirming that the sexualization of boys, girls and adolescents in media is a "major cultural problem", due to its presence on television, film, advertising, popular music and even the fashion industry (Lamb and Koven, 2019: 2).

Any of the following media-discourse practices constitute an index of sexualization: associating the value of a person to their attractiveness or sexual behavior, excluding other characteristics; defining physical attractiveness in a limited way, only in a erotic-sexual dimension; representing an individual as an object of others' sexual desire, without considering their action and decisionmaking capacity in an independent way, and inappropriately imposing sexuality on to a person (APA, 2007).

The sexualization of childhood has implications for their psychological and physical wellbeing (Merskin, 2004). From a psychological perspective, sexuality is configured from an age stratification and the development stages of a person. "Infancy and adolescence, considered transitional phases, are opposed to adulthood, whose sexuality is already a finished and lasting product" (Anastasia, 2019: 106). Different studies show that representations based on adult sexualization stereotypes of underaged women are more and more frequent (CNTV-Chile, 2012; Garrido et al., 2020; Grande-López, 2019; Maioli, 2017; Méndiz-Noguero, 2018; Lamb and Koven, 2019). This is noticed regularly in the fashion industry, "even for products in which such [sexual] references are not applicable" (Maioli, 2017: 24). Famous are the cases of Armani (adolescents aged between 14 and 15) and Vogue (girls between 5 and 7 years of age), for sending mixed messages: for adults, associating clothes to child seduction, and for children, not perceiving that they are being sold clothing (Medina-Heredia and Méndiz-Noguero, 2012). The sexualizing attributes identified in the academic literature can be grouped in three categories: the ones relative to people's dress code and nudity; the ones linked to the expressions and illustration which, occasionally, appear next to images of people or the clothing they wear, and the ones associated to people's gestures and posture (Díaz-Bustamante, LlovetRodríguez, and Narros-González, 2020: 78). 
The main problems derived from this erotization of girls are linked to issues of identity, body image, mental and psychological health, the reinforcement of gender stereotypes and, in the worst cases, gender violence, sexual abuse, pedophilia and sex tourism, among others (Egan and Hawks, 2008; Lamb and Koven, 2019, Medina-Heredia and Méndiz-Noguero, 2012. This is since body image "is a multifaceted construct and includes more than weight and shape", and because "it incorporates thoughts, beliefs, feelings and behaviors" (Larraín et al., 2013: 30).

In this sense, sexualized stereotypes can promote an image that girls might consider not only valid, but above all imitable, if they seek integration or social acceptance (Valiente-Bermejo, 2019: 36). This supposes, at the same time, that feminine bodies are frequently represented as a category of objects (Orellana, 2019).

\section{METHODOLOGY}

As a cultural artifact, advertising can install signifying objects for their appropriation by potential consumers (Vergara et al., 2018). That is to say, and according to Mitchell (1986, 2005), the advertising image, as every image, can generate meaning (a relation with another entity) and sense (an orientation regarding the signified reality). Due to this, we adopted an interpretive epistemological perspective and a qualitative methodological approach since we understand the path to the research object — the sexualization of children in advertising through stereotypes-as an interpretation exercise with high degrees of subjectivity. The semiotic works of Barthes (1986 [1964]) and Williamson (1978) inspired this research design, as well as of McQuarrie and Mick (2003) and Kettemann (2014).

The analysis features two stages. First, we seek to identify those aspects which could convey a sexualizing stereotype in the advert. The structural aspects of the image are described, according to the following categories (Barthes, 1986): the linguistic message, or the set of verbal signs in the advert, whose function is to anchor or delimit the general meaning; the coded iconic message, or the nonverbal signs which represent natural objects (people, things, places, etc.), involving a more or less defined meaning, and the non-coded iconic message, or the set of visual grammar elements (color, shape, texture, etc.) which acquire a specific meaning due to their relation with the other two types of messages.

In the second stage, we seek to recognize the meanings contained in the configuring elements of the stereotype from the erotization-sexualization dimension. We resort to two analysis models: the distinction between denotation and connotation (Barthes, 1971) and the concept of referent systems (Williamson, 1978). Denotation corresponds to the evident and objective meaning based on the original sense of the sign/text. Connotation is an underlying and subjective meaning based on the extension of the text's original intention from its link with historical, ideological, and cultural matrices. According to the referent systems concept, the connotation is configured and explained ideologically due to the appeal of the advert to specific sets of beliefs, associated with social groups and 
issues. In our case, the referent system is the subject of women stereotyping and child sexualization, described in the theoretical framework.

We opted for an intentional sampling design based on the adverts attached to the citizens' demands before the CONAR (one ad per brand). These three pieces also had most significant circulation in social and national media during the controversy. Since complaints were made a couple of days before the launch of the campaigns, the three brands involved only managed to display very few adverts and had to withdraw all the pieces and catalogs from their platforms and the media after CONAR's ruling, which was favorable to the claimants. Consequently, it is impossible to access the adverts from official sources and the complete catalog of images that were part of the campaigns. Considering the space limitations of a scientific paper, it would be unfeasible to offer a detailed account for a more extensive case corpus.

The images, shown in Figures 1, 2, and 3, were obtained from the Twitter accounts belonging to individuals and from a foreign media. Out of respect for the Council's decision to protect the girls' identities, the images included here hide their faces, which is also related to broader ethical challenges of visual research in studies of girlhood (Fink and Lomax, 2016).

\section{RESULTS}

Figure 1 shows a poster for socks brand Monarch, placed on a shop window, whose content also circulated in social media in the form of an advert. This was the image that triggered the controversy, mainly because of the girl-model's attire and pose.

\section{Figure 1. Back to school campaign advert by Monarch}

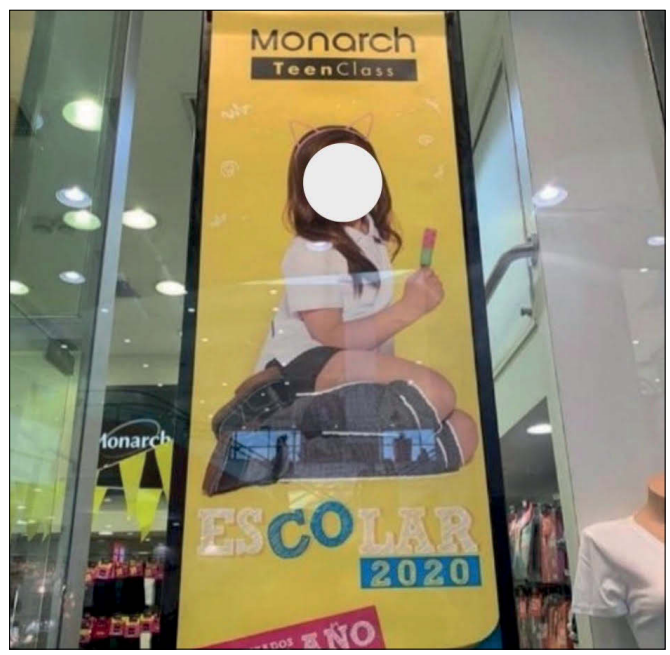


The linguistic message features, in the upper part of the advert, the brand's name with the tagline associated to the campaign ("Monarch" - "Teen Class"), while in the lower part it shows the name of the promotion ("Escolares 2020", Schoolchildren, 2020) along with a slogan related to the product's quality ("Garantizados todo el año" - "Guaranteed all year"). From the point of view of the coded iconic elements, the image is composed by the girl, who might be aged between 8 to 10, her attire and accessories. The model has Caucasian features (light skin, brown hair) and sports a common school uniform in Chile (white pique polo shirt, short skirt or short — it is not clearly distinguishable - grey socks and black shoes). In her head she wears a headpiece or diadem, whose upper part simulates the silhouette of a cat (pointed ears). In her hand she holds a red and green popsicle.

Regarding non-coded iconic elements, the image prominently features yellow as background, on top of which there are some unidentified shapes, which seem to be drawings or doodles made by children of the girl's age. While the verbal message on the upper part features the brand's typography, the lower part simulates handwriting, with print characters, written in colored chalk (white, blue, and red). The photograph of the girl features a semi-frontal long shot, neutral angle (at the height of the subject's look). Her lips look red.

In denotative terms, the girl's pose, which does not seem spontaneous or comfortable, is a signifier element that refers to the intentional character of her conduct: she is posing for the camera. Her attire is a signifier of her student condition, which emphasizes her childlike character. Her long hair and hairstyle are a signifier of her femininity. Her red lips are a signifier of a sign: she has tasted the popsicle. Finally, the cat-eared headpiece, an accessory that does not belong to the school uniform attire, is a signifier of her intention of customizing her appearance, i.e., give herself a style. Based on these elements, it is possible to notice a connotative signification of sensuality. The pose, direct look at the viewer, short skirt, the hair, and the red lips configure a system that not only appeals to the feminine character of the photographed subject, but especially to the sensitive dimension of her attractiveness, her outer beauty. In this framework, the headpiece alludes to the figure of a cat, an animal commonly associated - especially in its female gender- to sensuality. All these factors described and interpreted make it possible to recognize a sexualizing female stereotype, since the image narrows down the girl's identity to her physical condition and to attitudes associated to the area of eroticism, i.e., of sexual arousal and, above all, the implicit prohibition in her (see for example Bataille, 1997).

Figure 2 features an advert by underwear brand Mota, circulated in a digital and print catalogue. Its linguistic message, at the center of the image, only says "Niños Mota" -"Mota'Children". Under this slogan, a code is shown (MT-4211), repeated several times. 
Figure 2. Back to school campaign advert by Mota

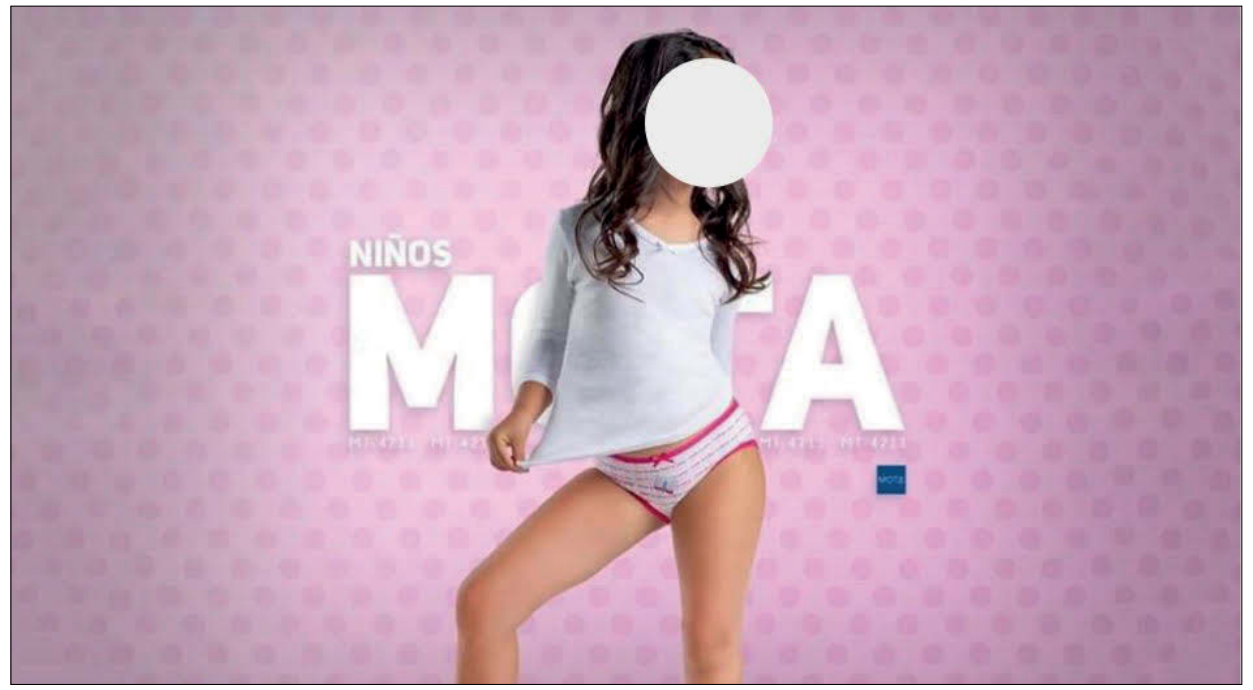

Source: <https://actualidad.rt.com/actualidad/343286-hipersexualizacion-ninas-campanas-publicitarias-criticas-chile>

Retrieved on August 20, 2020.

Regarding the coded iconic elements, the image is composed by a girl of about 10 years of age, who sports white underwear with pink designs and a white long-sleeved shirt, which in the lower part of its neck has a small ribbon. The model, of Caucasian features (light skin, brown hair), wears her hair loose and wavy. She is slim. She makes a hip movement towards her left while pulling her shirt with her right hand.

Concerning the non-coded iconic aspects, the image predominantly features pink, which covers the background as it were a canvas, which also features a dark pink polka dot design, the same color as the girl's underwear. Except for the white in the clothes and slogan, the only chromatic variation is the brand logo, which is blue, very small, and placed to the left of the minor. The image is a frontal medium-long or "knee" shot (not showing her ankles) at the center of the advert. In the case of the slogan, the word "Mota", in big typography, is half-covered by the girl.

In denotative terms, like the previous case the girl's pose is a signifier that alludes to her intention of posing for the camera. Her gesture, twisting her hip and grabbing her shirt, mimics the movement of a model on a runway and accentuates the curve of her waist. Her attire, which corresponds to underwear, is a signifier of a situation of intimacy. Her long and loose hair and wavy hairstyle, falling on her shoulders, is a signifier of her femininity. The predominant pink color has the same meaning, although it implies a certain infantilization.

These elements make possible to recognize a connotative signification of sensuality. Notwithstanding, this differs from the previous case, since in this case there is a component of imagination: the fact that the girl is wearing underwear and is in an undetermined place gives the image a certain dreamlike character, since she 
196 is posing for someone invisible in an impossible place, which does not represent any space pertaining to infancy (e.g., her bedroom). The girl's attitude could have a in playful character, as if she were mimicking a professional model. However, showing $-\quad$ her without context diminishes this option. It would be different if she were with friends in a pajama party, or with her mother, posing in front of a mirror. The lack of reference to a concrete space-time implies the inexistence of a truly appropriate context for the girl's attitude. In consequence, in this advert it is also possible to recognize a sexualizing female stereotype, since the girl is utilized to represent a narrowed and objectified vision of the feminine, with a sexual arousal.

Finally, Figure 3 shows an advert by footwear brand CMoran. Its linguistic message features the brand's name and the slogan for the campaign ("Back to school", in English in the original) in the upper part.

\section{Figure 3. Back to school campaign advert by C Moran}

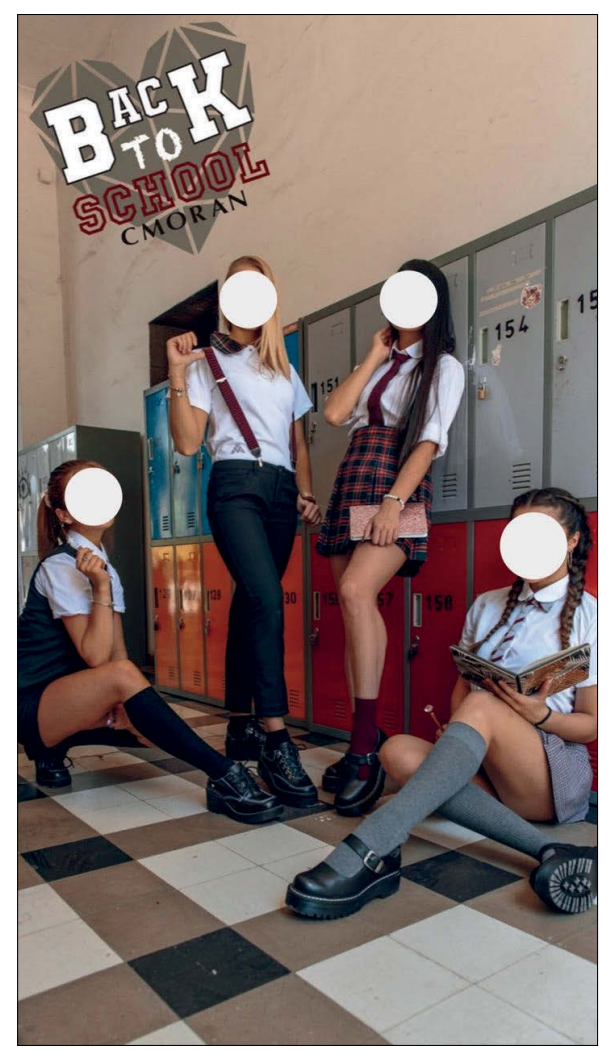

Regarding the coded iconic message, four adolescent girls with different school attire posing for the camera in front of lockers, in what is supposedly a school. Two of the girls have Aryan-Caucasian features (light skin, blond hair). The other two 
have a more Latin appearance (brown skin, brown or dark hair). The first girl, to the left, on the lower part of the image, squatting on one leg and with the other stretched, sports a short jumper typically used in Chilean public schools (blue with a white blouse). The second girl, to her left, is standing and sports blue pants with suspenders and a white t-shirt. The third girl is also standing, leaning on the lockers, and sports a plaid skirt with a white blouse and a tie in tones that match the skirt. The last girl is sitting on the floor, with semi-crossed legs, and sports a short grey skirt, up to the height of her thigh, a white blouse and a grey tie. All of them wear makeup and have their hair done and are wearing black school uniform shoes.

Among the non-coded iconic aspects, the upper part of the image features the slogan in big letters and the apparent figure of a grey heart, whose interior lines or folds emulate an origami. The typography alludes to high school films and American series' aesthetics. Given the place where the scene takes place -a hallway corridor with lockers-, the image predominantly features grey and opaque tones, except for some red and blue lockers. The photograph shows a long shot with a $3 / 4$ view, which reveals the corridor in perspective.

In denotative terms, the adolescents' pose is a signifier that refers to their intention of posing for the camera. Their attire is a signifier of their student condition, even though, unlike what occurs in the first case, the overall style they adopt, their hairstyle, makeup and even their accessories, distance them from any childlike and adolescent character. The femininity these details represent is rather of an adult nature or seeks to signify a certain adulthood.

In the light of these elements, this image connotatively signifies sensuality. However, it differs from the previous images not only because of the exposure component, since the young girls are there to be seen, but also because of the strong identity character, almost tribal, which the image conveys to a public and functional space, like the locker hallway corridor. It is true that the content of the lockers is private and representative of individuality. However, the hallway corridor shows the uniformity proper of a stop-by place. The key is the presence of the tribe: the popular girls turn a common place into a special one. In addition, in this case, the basis of popularity is sensuality. The only elements that refer to going back to school, apart from the uniforms, are accessories, a bright pink notebook, which looks like a clutch handbag, and an odd-looking notebook, with a pen with a bright ornament.

It is also possible to recognize a sexualizing female stereotype, since the adolescent girls' identity -even in group terms- is constructed from their physicalsexual appeal, which is at the same time explained by an exposure desire.

\section{CONCLUSIONS}

The analysis carried out makes it possible to conclude that the three images that triggered the controversy about the sexualization of girls and adolescent girls in Chile give an account of a sexualizing female stereotype, and that their signification is anchored in a sensuality constructed by an adult femininity, an ambiguous relation with the infant world, whose key signifying element is the 
intentionality of the body (in order to be sexy one has to adopt a deliberate pose, lacking spontaneity). In this sense, the presence of sexualization signs described by the APA (2007) is confirmed, especially the inappropriate imposition of sexuality on minors and the association between a person's value and their physical appeal.

Results confirm, regarding the studied cases, the trend noted by the literature about the importance of sexuality and eroticism as advertising arguments for the promotion of goods, even in campaigns that feature girl-models (MedinaHeredia and Méndiz-Noguero, 2012) or aimed at young girls. In this sense, it is curious that these brands build their value proposition based on risky benefits of self-expression (Aaker, 1996: 96-101), due to the social judgment they involve. Another interpretation could be that, not mediating this controversy might mean an advance towards the normalization of this kind of marketing strategies.

The stereotypes present in the novel/film "Lolita" or the "sexy bomb" (Liotard and Jamain-Samson, 2011) still operate in the public space and mass media as a contemporary source of the sexually attractive girl or adolescent girl stereotype, who seem to turn -willfully- into objects of desire. In the case of the first two images, the bodies of girls aged between 8 and 10 become stereotypes of "Lolita" bodies, regardless of not having the body image of an adolescent yet. Regarding the image of the adolescents, set in a school context, some of the representations might get close to the "Lolita" as well as the "sexy bomb" stereotypes.

The social representations offered by the media and social media constitute a growing problematic area, due to their capacity of normalizing certain practices according to commercial interests. This kind of depictions significantly contribute to develop a particular imaginary of childhood and the possible legitimation of their early erotization, views broadly criticized by organizations in charge of caring for children's health and to protect their rights. These advertising practices are not new, as emblematic cases of important fashion brands like Armani and Vogue demonstrate. Their dissemination through media tends to renew stereotypes present in society, though incompatible with the current debate on childhood and its protection.

It is curious that in a context in which the already mentioned advertising code of ethics in Chile points out that "advertising must avoid any form of appeal to sexuality, especially in situations or images that present minors in attitudes of eroticism or seduction" (CONAR, 2018, art. 21) these visual strategies were chosen to promote socks, underwear, and footwear. Even though the visual treatment of the pieces might be a differentiation resource, beyond the advertising argument related to the product's quality over others, to promote brand attributes based on intangible values, such as being noticed, success, and social acceptance linked to physical appearance; it overdoes in the use of girls and adolescent girls' bodies.

While these advertising arguments are recurring in general at a media level, revealing dimensions still latent in society, the current sociocultural context presents an increasingly critical sense regarding these kinds of discourses. Their role and social responsibility as public space agents of dissemination and validation of certain stereotypes and social imaginaries is not neutral, and the citizens, as in the case of the controversy that took place in Chile, are not willing to normalize these kinds of practices with marketing and commercial purposes. 
This research has been funded by the National Agency of Research and Development (ANID, Chile). Research Project: The Media Construction of Childhood: an approach from news, advertising and institutional discourses (FONDECYT Iniciación 111910462019/2022). Principal Investigator (PI) Rayén Condeza Dall’Orso).

Rayén Condeza Dall'Orso (rcondeza@ uc.cl) holds a PhD from the University of Montreal, a Master of Science in Education, and a degree in journalism from UC Chile. She is Associate Professor in communication at Pontificia Universidad Católica de Chile [Pontifical Catholic University of Chile (UC)], where she directed the master's degree in Communication and Education. Her research focuses on children, youth, and the media; the appropriation of the media and ICT

Pablo Matus (pmatus@uc.cl) is professor at the School of Communications, at Pontificia Universidad Católica de Chile [Pontifical Catholic University of Chile (UC)], where he teaches semiotics, discourse analysis, storytelling, and communication theory. He holds a PhD in Communication Sciences, a Master's in Strategic Communications, and a BA in Journalism, besides diplomas in Higher Education, Organizational Development,

Enrique Vergara-Leyton (evergaral@uc.cl) holds a PhD in Communication from The Autonomous University of Barcelona. Associate Professor at Pontificia Universidad Católica de Chile [Pontifical Catholic University of Chile (UC)]. He did an internship as a visiting professor at the Ramon Llul University (Spanish Agency for International Cooperation scholarship) and a postdoctoral research stay at Pompeu Fabra University, Barcelona. Among his research, he has participated in numerous projects funded for education and applied communication for social change. Among recent research funded by the National Agency of Research and Development (ANID, Chile) she is PI of The Media Construction of Childhood: an approach from news, advertising and institutional discourses (FONDECYT Iniciación 11191046-2019/2022). She is Editor-in-Chief of the scientific journal of communications Cuadernos.info and researcher at COES, Centre for Social Conflict and Cohesion Studies.

and Public Opinion. His lines of research are media discourse (advertising and journalism), strategic communication and communication theory. In these fields, he has published articles on the dystopian nature of environmental campaigns, the enunciative strategies of university advertising, the representation of citizen interests in electoral propaganda, and CSR communication practices in Latin America.

by the National Agency of Research and Development ANID (Chile) on consumption, advertising, and Chilean iconographic heritage. $\mathrm{He}$ is a member of the Arts and Architecture Study Group (National Fund for Scientific and Technological Development, ANID); member of the Area Committee of Social, Political and Communication Sciences (National Accreditation Commission CNA-Chile) and reviewer in different scientific journals in Europe and Latin America. 


\section{References}

Aaker, David (1996). Building Strong Brands. New York: The Free Press.

Amâncio, Ligia (1993). "Stereotypes As Ideologies. The Case of Gender Categories". Revista de Psicología Social, 8(2), pp. 163-170.

Anastasia, Pilar (2019). "Erotización infantil y gramáticas afectivas: Discurso sobre la infancia en la era 2.0 en Argentina". Sexualidad, Salud y Sociedad, 31, pp. 101-118.

Anderson, Benedict (1993). Comunidades imaginadas. Reflexiones sobre el origen y la difusión del nacionalismo. Ciudad de México: FCE.

APA (2007). Report of the APA Task Force on the Sexualization of Girls. Washington: American Psychological Association.

Azevedo-Queiroz, Marta María and Alves dos Santos Moura Fé, Flalrreta (2018). "Guisabashow. Niño-adulto show. Mercantilización de la infancia en tiempos de Instagram". Revista Luciérnaga/Comunicación, 10(19), pp. 62-70.

Baczko, Bronislaw (1991). Los imaginarios sociales. Memorias y esperanzas colectivas. Buenos Aires: Nueva Visión.

Bailey, Reg (2011). Letting Children be Children. Report of an Independent Review of the Commercialization and Sexualisation of Childhood. London: The Stationnary Office.

Barthes, Roland (1971). Elementos de semiología. Madrid: Alberto Corazón.

—. (1986). "Retórica de la imagen". Lo obvio y lo obtuso. Barcelona: Paidós, pp. 29-47.

Bataille, George (1997). El erotismo. Barcelona: Tusquets.

Berger, Arthur Asa (2011). Ads, Fads and Consumer Culture. Lanham: Rowman and Littlefield.

Bragg, Sara and Buckingham, David (2013). "Global Concerns, Local Negotiations and Moral Selves: Contemporary Parenting and the 'Sexualization of Childhood' debate". Feminist Media Studies, 13(4), pp. 643-659.

Cáceres, María Dolores and Díaz, Paloma (2008). "La representación del cuerpo de la mujer en la publicidad de revistas femeninas".
Estudios sobre el Mensaje Periodístico, (14), pp. 309-327.

Caro, Antonio (2007). "Fundamentos epistemológicos y metodológicos para un estudio científico de la publicidad". Pensar la Publicidad, 1(1), pp. 55-82.

-. (2014). "Understanding Advertising to Transform Society". Cuadernos.info, (34), pp. 39-46.

Carretero-García, Ana (2014). "Publicidad sexista y medios de comunicación". Revista CESCO de Derecho de consumo, 10, pp. 130-142.

Castoriadis, Cornelius (1983). La institución imaginaria de la sociedad. Vol. 1: Marxismo y teoría revolucionaria. Barcelona: Tusquets.

Cervilla-Fernández, Ariadna and MarfilCarmona, Rafael (2019). "Publicidad e infancia en Instagram. Análisis del uso de la imagen de niños y niñas por parte de madres influencers". In: Liberal-Ormaechea, Sheila and Mañas-Viniegras, Luis (coord.). Las redes sociales como herramienta de comunicación persuasiva. Madrid: Mc Graw Hill, pp. 201-211.

CNTV-Chile (2012). "Sexualización de la niñez en los medios. El debate internacional". Consejo Nacional de Televisión de Chile. Available at: <https://www.cntv.cl/wp-content/ uploads/2021/05/Sexualizacion-de-la-Ninezen-los-Medios-el-Debate-Internacio.pdf $>$. Accessed 24 May 2021.

CONAR (2018). "Código de ética del Consejo de Autorregulación y Ética publicitaria de Chile, VI versión, 2018". CONAR. Available at: <https://www.conar.cl/codigo-etica/>. Accessed 24 May 2021.

—. (2020a). "Fallo del caso №1133". CONAR. Available at: <https://www.conar.cl/ wp-content/uploads/2020/03/Rol-1133-FalloConar.pdf $>$. Accessed 24 May 2021.

—. (2020b). "Fallo del caso №1134". CONAR. Available at: <https://www.conar.cl/ wp-content/uploads/2020/03/Rol-1134-CMoran-IA-1.pdf>. Accessed 24 May 2021. 
—. (2020c). "Fallo del caso №1135". CONAR. Available at: <https://www.conar.cl/ wp-content/uploads/2020/04/Rol-1135-FalloReconsideración.pdf $>$. Accessed 24 May 2021.

Díaz-Bustamante, Mónica and Llovet-Rodríguez, Carmen (2017). “¿Empoderamiento o empobrecimiento de la infancia desde las redes sociales? Percepciones de las imágenes de niñas sexualizadas en Instagram". El Profesional de la Información, 26(1), pp. 77-87.

Díaz-Bustamante, Mónica; Llovet-Rodríguez, Carmen, and Narros-González, María José (2020). "Perceived Sexualization in Girls' Fashion Stylings: A Spain-China Cross-Cultural Analysis". Comunicar, 65, pp. 77-87.

Egan, Danielle R. (2013). Becoming Sexual: A Critical Appraisal of the Sexualization of Girls. Cambridge: Polity.

Egan, Danielle R. and Hawks, Gail (2008). "Girls, Sexuality and the Strange Carnalities of Advertisements: Deconstructing the Discourse of Corporate Paedophilia". Australian Feminist Studies, (57), pp. 307-322.

Eisend, Martin (2010). "A Meta-Analysis of Gender Roles in Advertising". Journal of the Academy of Marketing Science, 38(4), pp. 418-440.

El Dínamo (February 11, 2020). "Monarch decide retirar campaña tras acusaciones de 'sexualizar' a niña". Available at: <https://www. eldinamo.cl/actualidad/2020/02/11/monarchdecide-retirar-campana-tras-acusaciones-desexualizar-a-nina/>. Accessed 24 May 2021.

Escobar, Juan Camilo (2000). Lo imaginario. Entre las ciencias sociales y la historia. Medellín: ESFIT University.

Espinoza, Natalia (February 11, 2020). "Hipersexualización de niñas: El debate que han generado en redes sociales distintas campañas publicitarias". Available at: <https:// www.elmostrador.cl/braga/2020/02/12/ hipersexualizacion-de-ninas-el-debate-quehan-generado-en-redes-sociales-distintascampanas-publicitarias/>. Accessed 24 May 2021.

Feenstra, Ramón (2014). Ética de la publicidad. Retos en la era digital. Madrid: Dykinson.
Fink, Janet and Lomax, Helen (2016). "Sharing Images, Spoiling Meanings? Class, Gender and Ethics in Visual Research with Girls". Girlhood Studies, 9(3), pp. 20-36.

Francisco-Heredero, Inés de (2019). "La (in)definición del sexismo publicitario: De la lectura académica a la intervención social". Pensar Public, 13, pp. 147-170.

Garrido, Mónica (21 de agosto, 2020). "Netflix se disculpa por polémico póster acusado de sexualizar a menores". LaTercera.com. Available at: <https://www.latercera.com/ culto/2020/08/21/netflix-se-disculpa-porpolemico-poster-acusado-de-sexualizar-amenores/>. Accessed 24 May 2021.

Garrido Martinez-Salazar, Felipe.; SoneraMarcos, Laura.; García-Fernández, Pilar M.; Montagni, Isabel, and González-Caballero, Juan Luis (2020). "Representación de la imagen del menor en la publicidad difundida a través de internet". An Pediatr (Barc), 93(3), pp. 177-182.

Gill, Rosalind (2012). "The Sexualisation of Culture?". Social and Personality Psychological Compass, 6/7, pp. 483-498.

Goffman, Erving (1976). Gender Advertisements. New York: Harper and Row.

Gómez, Pedro Arturo (2001). "Imaginarios sociales y análisis semiótico. Una aproximación a la construcción narrativa de la realidad". Cuadernos, (17), pp. 195-209.

González-Anleo, Juan M.; Cortés del Rosario, María, and Garcelán-Vargas, Deborah (2013). "Roles y estereotipos de género en publicidad infantil. ¿Qué ha cambiado en las últimas décadas?" Revista Internacional de Investigación en Comunicación aDResearch ESIC, 18, pp. 80-99.

Grande-López, Víctor (2019). "La hipersexualización femenina en los medios de comunicación como escaparate de belleza y éxito". Communication Papers, 8(16), pp. 21-32.

Gunter, Barrie; Oates, Caroline; Blumberg, Fran, and Blades, Mark (2014). "Introduction". In: Blades, Mark; Oates, Caroline; Blumberg, Fran, and Gunter, Barrie (eds.). Advertising to 
Children. New Directions, New Media. London: Springer, pp. 1-16.

Hellín, Pedro (2007). Publicidad y valores postmodernos. Madrid: Siranda.

Herrett-Skjellum, Jennifer and Allen, Mike (1996). "Television Programming and Sex Stereotyping: A Meta-analysis". Annals of the International Communication Association, 19(1), pp. 157-186.

Jackson, Vinka [@VinkaJackson] (February 11, 2020). "La niñita no es 'teen', preteen ni nada, solo niña y chica..." [Tuit]. Available at: <https://twitter.com/VinkaJackson/ status/1227269107231252481>. Accessed 24 May 2021.

Jodelet, Denise (1986). "La representación social: Fenómenos, concepto y teoría". In: Moscovici, Serge (ed.). Psicología social II: Pensamiento y vida social. Buenos Aires: Paidós, pp. 469-494.

Jouanno, Chantal (2012). Contre l'hypersexualisation: Un nouveau combat pour l'égalité. Rapport parlementaire de Madame chantal Jouanno, Sénatrice de Paris. Paris: Sénat de la République.

Kettemann, Bernhard (2014). "Semiotics of Advertising and the Discourse of Consumption". In: Flath, B. and Klein, E. (eds.). Advertising and Design. Interdisciplinary Perspectives on a Cultural Field. Bielefield: Transcript, pp. 45-60.

Lamb, Sharon and Koven, Julie (2019). "Sexualization of Girls. Adressing Criticism of the APA Report, Presenting New Evidence". SAGE Open, October-December, pp. 1-15.

Larraín, María Elena; Arrieta, Monserrat; Orellana, Yasna, and Zegers, Beatriz (2013). "Impacto de imágenes femeninas presentadas por los medios de comunicación en adolescentes mujeres de la Región Metropolitana de Santiago de Chile". Psyche, 22(1), pp. 29-41.

Lin, Carolyn A. (1998). "Uses of Sex Appeals in Prime-Time Television Commercials". Sex Roles, 38(5/6), pp. 461-475.

Liotard, Philipe and Jamain-Samson, Sandrine (2011). "La 'Lolita' et la 'Sex Bomb', figures de socialisation des jeunes filles. L'hypersexualisation en question". Sociologies et Sociétés, 43(1), pp. 45-71.

Llovet-Rodríguez, Carmen; Díaz-Bustamante, Mónica, and Patiño-Alves, Beatriz (2016). "The Sexualization of Children Through Advertising, Fashion Brands and Media". Prisma Social, No. special 1, pp. 156-189.

Llovet-Rodríguez, Carmen; Díaz-Bustamante, Mónica, and Méndiz-Noguero, Alfonso (2019). "Estado de la cuestión sobre la sexualización infantil en el entorno digital y propuestas de alfabetización mediática". Doxa Comunicación, 28, pp. 223-240.

Lorenzini, María Eugenia [@KenaLorenziniL] (February 11,2020$)$. "\#MONARCH sexualizando a nuestras niñas... alimentando la pederastía..." [Tuit]. Available at: <https:// twitter.com/KenaLorenziniL/status/12271 94760387055617?s=20>. Accessed 24 May 2021.

Maioli, Esteban (2017). "Moda, cuerpo e infancia. Una indagación exploratoria sobre la erotización del cuerpo femenino a partir de las modalidades de la moda infantil". Buenos Aires: FLACSO. Available at: <https://fido. palermo.edu/servicios_dyc/proyecto graduacion/archivos/1247.pdf >. Accessed 24 May 2021.

McQuarrie, Edward F. and Mick, David Glenn (2003). "The Contribution of Semiotic and Rhetorical Perspectives to the Explanation of Visual Persuasion in Advertising". In: Scott, Linda M. and Batra, Rajeev (eds.). Advertising and Consumer Psychology. Persuasive Imagery: A Consumer Response Perspective. New York: Lawrence Erlbaum, pp. 191-221.

Medina-Heredia, Ana María and MéndizNoguero, Alfonso (2012). "La representación de la infancia en la publicidad: Panorama por el marco deontológico español". Pensar la Publicidad, 6(1), pp. 231-253.

Méndiz-Noguero, Alfonso (2018). "La representación del menor en la publicidad infantil. De la inocencia a la sexualización". Methaodos, 6(1), pp. 125-137. 
Mensa, Marta and Bittner, Verónica (2020). "Portraits of Women: Mexican and Chilean Stereotypes in Digital Advertising". Communication and Society, 33(1), pp. 63-78.

Merskin, Debra (2004). "Reviving Lolita? A Media Literacy Examination of Sexual Portrayals of Girls in Fashion Advertising". American Behavioral Scientist, 48(1), pp. 119-129.

Miller, David I.; Nolla, Kyle M.; Eagly, Alice H., and Uttal, David H. (2018). "The Development of Children's Gender-Science Stereotypes: A Meta-Analysis of 5 Decades of US Draw-a-Scientist Studies". Child Development, 89(6), pp. 1943-1955.

Mitchell, William John Thomas (2005). What Do Pictures Want? Chicago: Chicago University Press.

—. (1986). Iconology: Image, Text, Ideology. Chicago: Chicago University Press.

Moscovici, Serge (1984). "The Phenomenon of Social Representations". In: Farr, Robert M. and Moscovici, Serge (eds.). Social Representations. Cambridge: Cambridge University, pp. 3-69.

ONU Mujeres (1995). "Declaración y Plataforma de Acción de Beijing. Resoluciones aprobadas en la Cuarta Conferencia Mundial sobre la Mujer". Available at: <https:// www.un.org/womenwatch/daw/beijing/pdf/ BDPfA\%20S.pdf $>$. Accessed 24 May 2021.

-. (2020). "Doce esferas de especial preocupación". Available at: <https://www. unwomen.org/es/news/in-focus/csw59/ feature-stories>. Accessed 24 May 2021.

Orellana, Ramón Alejandro (2019). "La cosificación de la mujer en la publicidad". Publicitas, 7(1), pp. 47-58.

Petroll, M. and Damacena, C. (2012). "Apelo sexual na propaganda: Uma breve revisão da literatura e reflexão". FAMECOS, 19(2), pp. 567-585.

Pintos, Juan Luis (1995). "Orden social e imaginarios sociales". Papers, (45), pp. 101-127.

Ribero, Fabio (2009). "Publicidad erótica. A mayor impacto menor posicionamiento". Teoría y Praxis Investigativa, 4(1), pp. 39-45.
Richards, Jef and Curran, Catherine M. (2002). "Oracles on Advertising: Searching for a Definition". Journal of Advertising, 31(2), pp. 63-77.

Rosa, Annamaria Silvana de (2013). "Research Fields in Social Representations: Snapshot Views from a Meta-Theoretical Analysis". In: Rosa, Annamaria Silvana de (ed.). Social Representations in the Social Arena. New York: Routledge, pp. 89-124.

San Francisco, L. and Badal, I. (February 13, 2020). "Bown y publicidad infantil: 'Los padres tienen responsabilidad'”. La Segunda, p. 4.

Serrano, Carolina; Serrano, Héctor; ZarzaDelgado, Patricia, and Vélez-Bautista, Graciela (2018). "Estereotipos de género que fomentan violencia simbólica: Desnudez y cabellera". Estudos Feministas, 26(3), pp. 1-14.

Schneider, David J. (2004). The Psychology of Stereotyping. New York: Guilford.

Sherman, Aurora M.; Allemand, Haley, and Prickett, Shayla (2020). "Hypersexualization and Sexualization in Advertisements for Halloween Costumes". Sex Roles, 83(3/4), pp. 254-266.

Speno, Ashton Gerding and Aubrey, Jennifer Stevens (2018). "Sexualization, Youthification and Adultification: A Content Analysis of Images of Girls and Women in Popular Magazines". Journalism \& Mass Communication Quarterly, 95(3), pp. 625-646.

Stankiewicz, Julie M. and Roselli, Francine (2008). "Women As Sex Objects and Victims in Print Advertisements". Sex Roles, 58(7), pp. 579-589.

T13 (February 11, 2020). "Denuncian 'sexualización' de niña en publicidad de calcetines". Available at: <https://www.t13.cl/ noticia/nacional/denuncian-sexualizacionnina-publicidad-calcetines $>$. Accessed 24 May 2021.

Trindade, Eneus and Silva, José da (2009). “Antropología, comunicación e imágenes: Alternativas para pensar la publicidad y el consumo en la contemporaneidad". Pensar la Publicidad, 3(1), pp. 203-218. 
RAYÉN CONDEZA-DALL'ORSO, PABLO MATUS, ENRIQUE VERGARA-LEYTON

Urzúa, Nicole [@gueonakebrutal] (February 10, 2020). "Sorpresa, hombres publicistas diciendo que la pieza funada de Monarch..." [Tuit]. Available at: <https://twitter.com/ gueonakebrutal/status/12269536159417384 97>. Accessed 24 May 2021.

Valiente-Bermejo, Lucía (2019). "La escenificación de la violencia de género en el discurso publicitario". Comunicación, 1(17), pp. 35-52.

Vergara, Enrique (2006). "Publicidad: ¿la 'zanahoria metafísica' que mueve al burro, o el color de nuestro tiempo?". Trípodos, 18, pp. 157-164.

Vergara, Enrique; Garrido, Claudio; Condeza, Rayén, and Pino, Bárbara (2018) “Gráfica y consumo. Una aproximación a la publicidad de mall Parque Arauco". RChD: Creación y Pensamiento, 3(5), pp. 1-8.

Williamson, Judith (1978). Decoding Advertisements. Ideology and Meaning in Advertising. London: Marion Boyars. 